INTRODUCTION TO ACCOUNTANCY AND FINANCE 


\section{TITLES IN THIS SERIES}

Published

R. J. Briston

Introduction to Accountancy and Finance

H. K. Jaeger

The Structure of Consolidated Accounting

Ernest Laidler

Variance Accounting

Frank Osborn

Costing and Control of Materials

R. M. S. Wilson (editor)

Financial Dimensions of Marketing 


\section{Introduction to Accountancy and Finance}

\section{R. J. BRISTON}

Contributors
R. J. Briston
C. McGeehan
J. R. Davies
W. McInnes
P. N. Dean
A. J. Millar
C. Edwards
E. P. Minnis
S. Ewing
L. Oakes
C. S. Greensted
R. Perks
D. Lyall
C. R. Tomkins 
๑) R. J. Briston, J. R. Davies, P. N. Dean, C. Edwards,

S. Ewing, C. S. Greensted, D. Lyall, the estate of C. McGeehan,

W. McInnes, A. J. Millar, E. P. Minnis, L. Oakes,

R. Perks, C. R. Tomkins 1981

Softcover reprint of the hardcover 1st edition 1981 978-0-333-24669-6

All rights reserved. No part of this publication

may be reproduced or transmitted, in any form

or by any means, without permission.

First published 1981 by

THE MACMILLAN PRESS LTD

London and Basingstoke

Associated companies in Delhi Dublin

Hong Kong Johannesburg Lagos Melbourne

New York Singapore and Tokyo

ISBN 978-0-333-30101-2 ISBN 978-1-349-16515-5 (eBook)

DOI 10.1007/978-1-349-16515-5

Typeset in 10/12 Press Roman by

STYLESET LIMITED

Salisbury. Wiltshire

This book is sold subject to the standard conditions of the Net Book Agreement.

The paperback edition of this book is sold subject to the condition that it shall not, by way of trade or otherwise, be lent, resold, hired out, or otherwise circulated without the publisher's prior consent in any form of binding or cover other than that in which it is published and without a similar condition including this condition being imposed on the subsequent purchaser. 


\section{CONTENTS}

Preface $\quad$ xv

List of Contributors $\quad$ xvi

1 Introduction to Financial Accounting 1

1.1 Introductory 1

(a) Nature and Purpose of Accounting 1

(b) Users of Accounting Information 1

(c) Historical Development of Accounting 4

1.2 Basic Concepts of Accounting 5

(a) The Balance Sheet 5

(b) The Balance-Sheet Equation $\quad 7$

(c) The Measurement of Profit 9

1.3 The Recording of Transactions 11

(a) The Ledger 11

(b) Double-entry Book-keeping $\quad 12$

(c) Books of Original Entry 14

(d) The Trial Balance $\quad 24$

$\begin{array}{lll}1.4 & \text { Final Accounts } & 25\end{array}$

(a) Relationship Between the Balance Sheet and the
Trading and Profit and Loss Account

(b) The Trading and Profit and Loss Account 26

(c) Year-end Adjustments $\quad 32$

(d) Depreciation $\quad 33$

(e) Disposal of Fixed Assets $\quad 38$

1.5 Partnership Accounts

(a) The Nature of Partnerships 40

(b) Appropriation Accounts and the Allocation of Profit 41 
vi Contents

(c) Commencement of a Partnership and the Introduction of a New Partner 47

(d) Goodwill $\quad 51$

(e) Retiral of a Partner 51

(f) Dissolution $\quad 51$

1.6 An Introduction to Company Accounts 54

(a) The Nature of Limited Liability Companies $\quad 54$

(b) Shares and Debentures $\quad 54$

(c) Trading, Profit and Loss and Appropriation Account 56

(d) Taxation $\quad 62$

$\begin{array}{lll}1.7 & \text { Manufacturing Accounts } & 62\end{array}$

1.8 Some Basic Accounting Concepts and Conventions 66

$\begin{array}{ll}\text { Questions and Exercises } & 69\end{array}$

$\begin{array}{ll}2 \text { Company Accounts } & 77\end{array}$

2.1 Development of Company Organisation $\quad 77$

(a) Limitations of Sole Trader and Partnership Trading 77

(b) Historical Development of Companies and Reporting Requirements

2.2 Content and Analysis of Company Accounts 84

(a) Raising of Finance $\quad 84$

(b) Accounting Implications of the Company Form of $\begin{array}{ll}\text { Organisation } & 89\end{array}$

(c) Review of Current Accounting Disclosure Provisions 91

2.3 Group Accounts

(a) Provisions of the Companies Acts Regarding Group Accounts

$\begin{array}{ll}\text { (b) The Preparation of Group Accounts } & 121 \\ \text { (c) The Group Balance Sheet } & 123\end{array}$

(d) Inter-Group Trading 132

(e) Group Profit and Loss Account 133

(f) The Merger Method of Preparing Group Accounts 136

(g) Treatment of Investments in Associated Companies $\quad 140$ 
2.4 Interpretation of Published Accounting Statements 141

(a) Profitability Ratios $\quad 141$

(b) Solvency Ratios $\quad 144$

2.5 Capital Reduction and Company Liquidation 150

(a) Redemption of Redeemable Preference Shares $\quad 150$

(b) Capital Reduction Schemes $\quad 151$

(c) Liquidations 151

Further Reading $\quad 152$

Questions and Exercises $\quad 153$

3 Introduction to Accounting Theory 162

$\begin{array}{lll}3.1 & \text { Introduction } & 162\end{array}$

3.2 The Determination of Periodic Profit 164

(a) The 'Net Assets' or 'Capital Maintenance' Approach to Profit Determination

(b) The Transactions Approach to Profit Determination Based on the Matching of Costs with Revenues

3.3 Recognition of Revenue and Expenses 167

(a) Timing of Revenue Recognition 167

(b) The Amount of Revenue to be Recognised 170

(c) Holding Gains and Losses $\quad 172$

(d) Recognition of Expenses 173

(e) Amount of Expenses to be Recognised 173

3.4 Stock Valuation and Cost of Goods Sold 174

(a) Specific Identification $\quad 175$

(b) First-in, First-out 175

(c) The Average Cost Method 177

(d) Last-in, First-out 177

(e) Interim Summary 180

$\begin{array}{lll}\text { 3.5 Depreciation of Fixed Assets } & 182\end{array}$

(a) The Evolution of Depreciation $\quad 183$

(b) Depreciation in Industry 183

3.6 Other Problems in the Measurement of Profit 188

Extraordinary Gains and Losses $\quad 188$ 
viii Contents

$\begin{array}{lll}\text { 3.7 The Balance Sheet } & 192\end{array}$

(a) The Nature of Assets 192

(b) The Valuation of Assets 195

(c) The Nature of Liabilities 199

(d) The Valuation of Liabilities $\quad 201$

$\begin{array}{lll}3.8 & \text { General Conclusion } & 205\end{array}$

Notes and References $\quad 206$

$\begin{array}{ll}\text { Questions } & 207\end{array}$

4 Financial Accounting Theory - an Overview 212

4.1 Methodology of Financial Accounting Theory 212

4.2 Investment Decisions and Accounting Information 214

4.3 Historical Development of Conventional Accounting 219

4.4 Current Problems with Conventional Accounting 221

$\begin{array}{ll}\text { 4.5 Income, Capital, and Value } & 227\end{array}$

4.6 Modifications for General Price Level Changes 227

4.7 Current Value Accounting 234

4.8 Professional Developments in the United Kingdom 241

$\begin{array}{ll}\text { Notes and References } & 249\end{array}$

$\begin{array}{ll}\text { Questions } & 250\end{array}$

5 Cost Accounting $\quad 252$

5.1 Corporate Objectives and Decision Making 252

5.2 Accounting as an Aid to Decision Making 254

$\begin{array}{lll}5.3 & \text { Costing Terminology } & 258\end{array}$

$\begin{array}{lll}5.4 & \text { Cost Behaviour } & 261\end{array}$ 
5.5 The Mechanics of Product Cost Analysis 265

(a) Direct Materials $\quad 266$

(b) Labour $\quad 269$

(c) Works Overheads $\quad 270$

5.6 Job Costing 280

$\begin{array}{lll}5.7 & \text { Process Costing } & 281\end{array}$

5.8 Standard Costing 282

(a) Introduction $\quad 282$

(b) Analysis of Material Variances $\quad 285$

(c) Analysis of Labour Variances $\quad 287$

(d) Analysis of Works Overhead Variances 288

(e) The Application of Variance Analysis 290

5.9 Control Through Budgets 292

5.10 Break-even Analysis, Contribution Theory and Decision Making 297

5.11 Product Profitability and Pricing Decisions 302

Further Reading $\quad 306$

Questions and Exercises $\quad 307$

6 Financial Management $\quad 319$

$\begin{array}{lll}6.1 & \text { Introduction } & 319\end{array}$

(a) Business Activity $\quad 319$

(b) The Financial Environment $\quad 320$

(c) Objectives of the Firm $\quad 321$

(d) Financial Management $\quad 323$

(e) Time Value of Money 323

6.2 Share Valuation $\quad 329$

(a) Introduction $\quad 329$

(b) A Share Valuation Model $\quad 330$

(c) Uncertainty and the Rate of Return 336

6.3 Capital Investment Appraisal 337

(a) The Nature of the Long-term Investment Decision 337

(b) Criteria for Investment Decisions under Conditions
of Certainty 
X Contents

6.4 The Effect of Risk

(a) The Measurement of Risk

(b) Attitudes Towards Risk

(c) Incorporation of Risk in Investment Decisions

6.5 Cost of Capital

(a) The Cost of Individual Sources of Finance 368

(b) Planning the Financial Structure

6.6 Dividend Policy

6.7 Inflation

Appendix 6.1

391

Appendix 6.2

392

Notes and References

393

Further Reading

393

Questions and Exercises

393

7 Accounting Reports and Security Analysis 402

$\begin{array}{lll}7.1 & \text { Introduction } & 402\end{array}$

7.2 The United Kingdom Stock Exchange 403

(a) History 403

(b) Functions $\quad 404$

7.3 Information Available to Investors and its Analysis 410

(a) Company Disclosure $\quad 410$

(b) Information Regarding Stock Exchange Transactions and its Analysis

(c) Other Information

(d) Fundamental Analysis v. Technical Analysis

7.4 Research into Stock Market Behaviour 424

(a) Share Valuation Models $\quad 424$

(b) Stock Market Efficiency $\quad 426$

(c) Investor Behaviour $\quad 429$

$\begin{array}{lll}7.5 & \text { Portfolio Selection } & 430\end{array}$ 
Notes and References $\quad 434$

Further Reading $\quad 435$

Questions

8 Government Accounting 438

$\begin{array}{lll}8.1 & \text { Introduction } & 438\end{array}$

8.2 The Central Government Financial System 440

(a) The Consolidated Fund $\quad 440$

(b) National Loans Fund $\quad 441$

(c) Issues from the Consolidated Fund 442

(d) Supply Services - Constitutional Principles 442

(e) Supply Procedure 444

(f) Form of the Estimates $\quad 445$

(g) Taxation 448

(h) Accounting for Departmental Spending 448

(i) Allied Services $\quad 450$

(j) Appropriation Accounts 451

(k) Role of the Treasury 452

8.3 Accountability $\quad 454$

(a) Internal Control $\quad 454$

(b) External Audit $\quad 455$

(c) Select Committees of the House of Commons 456

8.4 Improving the Quality of Government Budgets 458

(a) Alternative Bases of Accounting 458

(b) Budgeting and the Allocation of Resources 463

(c) Performance Budgeting and PPBS 464

(d) Multi-Year Costing $\quad 467$

(e) Zero-Base Budgeting (ZBB) 469

(f) Quantitative Evaluation of Outcomes $\quad 471$

(g) Cost-Benefit Analysis (CBA) 474

8.5 Accounting for Government Enterprises 477

Notes and References $\quad 486$

Further Reading $\quad 486$ 
xii Contents

9 Social Accounting $\quad 489$

9.1 Introduction to Social Accounting 489

9.2 National Income Accounts: Introduction 490

(a) Basic Concepts $\quad 490$

(b) Measurement of National Income $\quad 491$

(c) The Circular Flow of Income and National Product 491

9.3 National Income Accounts - Accounting Systems 495

(a) Basic Structure of System $\quad 495$

(b) Production Account 498

(c) Household Account 499

(d) Government Account $\quad 500$

(e) Capital Account $\quad 500$

(f) The Rest of the World Account 501

9.4 National Income Accounts - Some Major Problem Areas 502

(a) Problems of Double Counting 502

(b) Various Concepts of National Product $\quad 504$

(c) Defining the Scope of the National Product 505

(d) Proposals for Change in the Scope of National Income Accounting 508

(e) Intertemporal and International Comparisons of
National Product

9.5 The Other Main Elements of Social Accounts 512

(a) Input-Output Tables $\quad 512$

(b) Flow-of-Funds Accounting $\quad 515$

(c) National Balance Sheets $\quad 519$

$\begin{array}{ll}\text { Further Reading } & 520\end{array}$

10 Accounting Systems and Control $\quad 521$

$\begin{array}{ll}10.1 \text { Introduction } & 521\end{array}$

10.2 The Role of Information in Organisations 522

(a) Information for Planning and Control 524

(b) Operating Information $\quad 530$

$\begin{array}{ll}\text { 10.3 Financial Control Systems } & 531\end{array}$ 
10.5 The Design and Implementation of Integrated Information Systems

10.6 The Impact of Computers on Information Systems

10.7 Control of Large-Scale Projects

Notes and References

(a) A Graphical Explanation of a Product-mix Problem 556

(b) Opportunity Costing 559

(c) Possible Use for Divisionalised Companies $\quad 562$

(d) Capital Budgeting 565

11.5 Transfer Pricing 567

11.6 Capital Budgeting and Uncertain Cash Flows 574

$\begin{array}{ll}11.7 \text { Network Analysis } & 586\end{array}$

$\begin{array}{ll}11.8 \text { Conclusion } & 590\end{array}$

Appendix: Notes on Vectors and Matrices 591

Notes and References $\quad 598$

Questions and Exercises $\quad 599$

12 International Aspects of Accountancy and Finance 601

12.1 Evaluation, Financing and Control of Overseas Operations 601

(a) Introduction 601 
xiv Contents

$\begin{array}{ll}\text { (b) Evaluation } & 601\end{array}$

(c) Financing $\quad 608$

(d) Financial Planning and Control 610

(e) The Role of Multinationals 611

12.2 International Accounting Problems 612

(a) Accounting for Transactions in Different Currencies 612

(b) International Accounting Standards $\quad 625$

(c) Accounting in Developing Countries 632

Appendix 12.1 $\quad 635$

$\begin{array}{ll}\text { Appendix } 12.2 & 638\end{array}$

Notes and References $\quad 639$

Further Reading $\quad 640$

$\begin{array}{ll}\text { Questions } & 640\end{array}$

$\begin{array}{ll}\text { Index } & 643\end{array}$ 


\section{PREFACE}

The object of this text is to provide an extremely broad introduction to accountancy and finance. As such it is suitable both for academic and professional courses for which the lecturers wish to adopt a broad approach and for managers who wish to gain an understanding of these subjects which goes beyond the narrow professional approach found in more traditional texts.

From a teaching viewpoint it is hoped that lecturers will be attracted by the possibility of developing their own course by selecting for study those subjects which they regard as important out of the many areas covered herein. This is regarded as particularly important at the introductory level, where some teachers may wish to build up a general introductory course involving both the less technical aspects of accountancy and the theory of finance while others may prefer or be required to concentrate upon a more mechanical approach. This book is the first British introductory text to offer such flexibility at this level.

Although it is introductory in its emphasis it nevertheless covers in a very straightforward fashion relatively advanced topics such as accounting systems and control, portfolio theory, public sector accounting, national accounts, international accounting and the financial policy of multinationals. All of these topics are developed at a level which could be incorporated in introductory courses. 


\section{LIST OF CONTRIBUTORS}

R. J. BRISTON

J. R. DAVIES

P.N. DEAN

C. EDWARDS

S. EWING

C. S. GREENSTED

D. LYALL
Professor of Accounting and Finance, University of Strathclyde, 1972-9; currently Reader in Accounting and Finance, University of East Anglia

Senior Lecturer in Accounting and Finance, University of Strathclyde

Senior Lecturer in Accounting and Finance, University of Strathclyde

Lecturer in Accounting and Finance, University of Strathclyde

Senior Lecturer in Accounting and Finance, University of Strathclyde

Lecturer in Accounting and Finance, University of Strathclyde

Lecturer in Accounting and Finance, University of Strathclyde

The late

Senior Lecturer in Accounting and Finance, University CHARLES McGEEHAN of Strathclyde

W. MCINNES
A. J. MILLAR
E.P. MINNIS

L. OAKES

R. PERKS

C. R. TOMKINS

Lecturer in Accounting and Finance, University of Strathclyde

Lecturer in Accounting and Finance, University of Strathclyde

Senior Lecturer in Accounting and Finance, University of Strathclyde

Lecturer in Accounting and Finance, University of Strathclyde

Senior Lecturer in Accounting, University of Wales, Bangor

Professor of Finance, University of Bath 